\title{
MORPHOLOGICAL AND MOLECULAR CHARACTERISATION OF ECUMENICUS MONOHYSTERA (NEMATODA DORYLAIMIDA QUDSIANEMATIDAE) AND ITS PHYLOGENETIC RELATIONS FROM IRAN
}

\begin{abstract}
(*) Department of Plant Protection, College of Agriculture, Shahid Chamran University of Ahvaz, P.O. Box 61357-
\end{abstract} 83151, Ahvaz, Iran; - -mail s.azimi@scu.ac.ir

Azimi S. - Morphological and molecular characterisation of Ecumenicus monohystera (Nematoda Dorylaimida Qudsianematidae) and its phylogenetic relations from Iran.

Ecumenicus monohystera was collected from the rhizosphere of faba bean (Vicia faba L.) fields in Khuzestan province, south-western Iran. Morphological and morphometric data are provided for this species. Additionally, sequence of the D2-D3 expansion segments of 28S rRNA gene for this species was also used for molecular phylogenetic analysis. The phylogenetic relationships of E. monohystera in relation to representatives of the order Dorylaimida, obtained from Bayesian inference (BI) analysis of the D2-D3 sequences, are presented and discussed.

KEY WoRDs: 28S rRNA gene, Ecumenicus, morphology, morphometric, phylogeny.

\section{INTRODUCTION}

More than $80 \%$ of the most environmental stresssensitive nematode families belong to the orders Mononchida Jairajpuri, 1969 and Dorylaimida Pearse, 1942 (Holterman et al., 2008). Dorylaims, the representatives of the nematode order Dorylaimida, are probably the most diverse taxon within the phylum Nematoda. The families Dorylaimidae de Man, 1876 (with 24 valid genera and 336 valid species) and Qudsianematidae Jairajpuri 1965 (with 31 valid genera and 402 valid species) are two important, highly diverse, free-living, dorylaimid taxa (PEÑA-SANTIAGo and Alvarez-Ortega, 2014).

The genus Ecumenicus was proposed by Thorne in 1974 to accommodate a cosmopolitan species, E. monohystera (de Man, 1880) Thorne, 1974, transferred from Eudorylaimus Andrássy, 1959. The new taxon was characterized by its mono-opisthodelphic female genital system, a rather rare feature among members of Dorylaimoidea (PEÑASANTIAGO and ABOLAFIa, 2007). DAREKAR \& KHAN (1979) established a genus Indokochinema, with a single species, $I$. conicauda. This genus corresponds perfectly to Ecumenicus with ovary single, no prevulval uterin sac, oesophagus expanded posteriorly, amphids on lateral lips, spear small, tail short, conoid, so ANDRÁssy (1991) synonymized Indokochinema with Ecumenicus. The second species, Indokochinema ekramullahi Jana \& Baqri (1983), has been already synonymized by BAQRI \& COOMANS (1985) with Ecumenicus monohystera (ANDRÁSSY, 1991).

Peña-Santiago \& Abolafia (2007) studied the location of amphid aperture in E. monohystera with SEM and confirmed ANDRÁSSY's (1991) action, regarding Indokochinema as a junior synonym of Ecumenicus. According to ANDRÁSSY (1991), the genus Ecumenicus includes four species. E. monohystera is a cosmopolitan species and has also been reported from many countries (PEÑA-SANTIAGO and ABOLAFIA, 2007).
The present study aims to characterize E. monohystera from the rhizosphere of faba bean in Iran using morphological and molecular data. Additionally, the phylogenetic relationships of this species is evaluated on the basis of the D2-D3 expansion segments of the 28S rRNA gene.

\section{MATERIALS AND METHODS}

\section{NEMATODE SAMPLES}

Soil samples were collected from faba bean (Vicia faba L.) fields in Khuzestan province, south-western Iran. The JENKINS's (1964) method was used to extract the nematodes from soil samples. The collected specimens were killed by adding boiling formaldehyde solution (4\%), transferred to anhydrous glycerin according to DE GRISSE's (1969) method. Nematodes were mounted in a small drop of glycerin on permanent slides. Observations and measurements were done using a Leitz SM-LUX light microscope equipped with drawing tube. Some of the best-preserved specimens were photographed using an Olympus DP12 digital camera attached to an Olympus BX51 light microscope. Nematode species were identified based on morphological, morphometric and molecular characters. SIDDIQI, 2000 used for the abbreviations and ratios used in the morphological description.

\section{DNA EXTRACTING, PCR AND SEQUENCING}

For molecular analyses, a single female was picked out from samples, examined in drop of distilled water on a temporary slide under the light microscope, transferred to 7 $\mu \mathrm{l}$ of AE buffer (10 mM Tris-Cl, 0.5 mM EDTA; pH 9.0) on a clean slide, and then crushed using a cover slip. The suspension was collected by adding $20 \mu \mathrm{l}$ AE buffer. Each DNA sample was stored at $-20^{\circ} \mathrm{C}$ until used as a PCR template (PEDRAM et al., 2011). The D2-D3 expansion 
segments of the 28S rDNA was amplified using the forward D2A (5'-ACAAGTACCGTGAGGGAAAGTTG-3') and reverse D3B (5'-TCGGAAGGAACCAGCTACTA-3') primers (NUNN, 1992). PCR reactions of $25 \mu \mathrm{l}$ were made with $14 \mu$ of distilled water, $2.5 \mu$ of $10 \times$ PCR buffer, 0.5 $\mu \mathrm{l}$ of dNTP mixture, $1.5 \mu \mathrm{l}$ of $50 \mathrm{mM} \mathrm{MgCl} 2,1 \mu \mathrm{l}$ of each primer $(10 \mathrm{pmol} / \mu \mathrm{l}), 0.5 \mu \mathrm{l}$ of Taq polymerase (CinnaGen, Tehran, Iran, c. $5 \mathrm{U} / \mu \mathrm{l})$, and $4 \mu \mathrm{l}$ of DNA template. The thermal cycling program was as follows: initial denaturation at $95^{\circ} \mathrm{C}$ for $6 \mathrm{~min}$, followed by 35 cycles of denaturation at $94^{\circ} \mathrm{C}$ for $30 \mathrm{~s}$, annealing at $55^{\circ} \mathrm{C}$ for $30 \mathrm{~s}$ and extension at $72^{\circ} \mathrm{C}$ for $1 \mathrm{~min}$. A final extension was performed at $72^{\circ} \mathrm{C}$ for 10 min (PEDRAM et al., 2011). Amplification success was evaluated electro phoretically on $1 \%$ agarose gel. The PCR products were purified using the QIAquick PCR purification kit (Qiagen $\left.{ }^{\circledR}\right)$ following the manufacturer's protocol and sequenced directly using the PCR primers with an ABI 3730XL sequencer (Bioneer Corporation, South Korea). The newly obtained sequence was deposited into the GenBank database (accession number MF667960).

\section{PHYLOGENETIC ANALYSES}

The newly obtained sequence of the D2D3 fragments of $28 \mathrm{~S}$ rDNA and additional sequences of relevant taxa selected after a BlastN search, were aligned by Clustal X2 (http://www.clustal.org/) using the default parameters. The outgroup taxa were chosen according to a previous study (Holterman et al., 2008). Model of base substitution was selected using Mr Model test 2 (NYLANDER, 2004), and based on the Akaike criteria. A general time reversible model, including among-site rate heterogeneity and estimates of invariant sites (GTR $+\mathrm{G}+\mathrm{I})$, was selected for the phylogenetic analyses. Bayesian analysis was used to infer the phylogenetic tree on MrBayes v3.1.2 (RONQUIST \& HuelsenBeCK, 2003), running the chain for one million generations. After discarding burn-in samples and evaluating convergence, the remaining samples were retained for further analyses. The Markov chain Monte Carlo (MCMC) method within a Bayesian framework was used to determine equilibrium distribution and help estimate the posterior probabilities of the phylogenetic tree (LARGET \& SiMON, 1999) using the 50\% majority rule. The Bayesian posterior probabilities (BPP) higher than $50 \%$ were given on appropriate clades. The output file of the phylogenetic program was visualized using Dendroscope V.3.2.8 (HUSON $\&$ SCORnAVACCA 2012) and re-drawn in CorelDRAW software version 12 .

\section{RESULTS AND DISCUSSION}

Ecumenicus monohystera (de Man, 1880) Thorne, 1974 (Figs I and II)

Measurements: Table 1.

\section{DESCRIPTION}

Female: Body straight to slightly ventrally curved upon fixation; Medium-sized, 0.9-1.2 mm long. Cuticle very

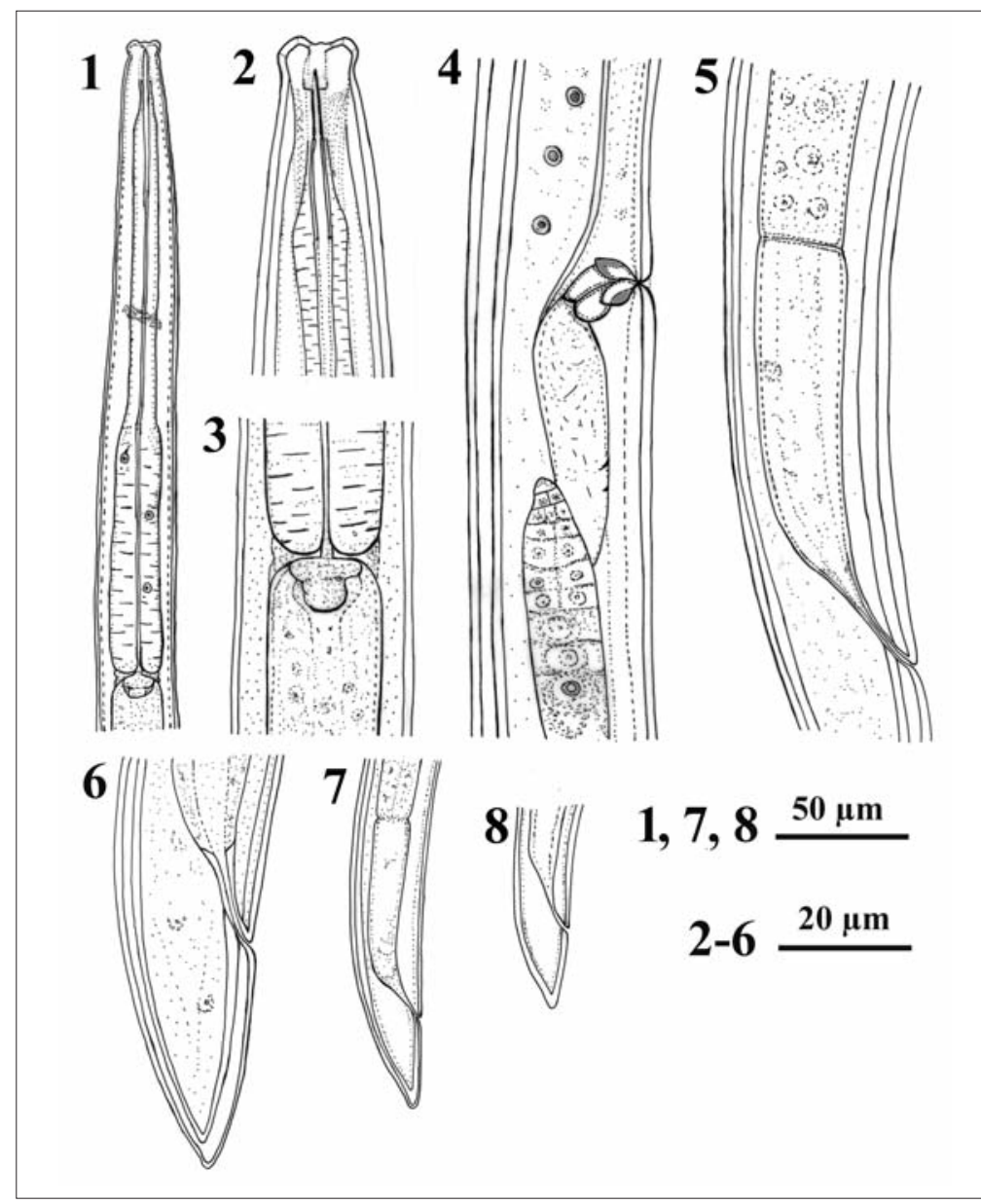

Fig. I - Ecumenicus monohystera - 1. Pharynx; 2. Lip region; 3. Pharyngeal cardia; 4. Vulval region; 5. Prerectum region; 6-8. Posterior region. 

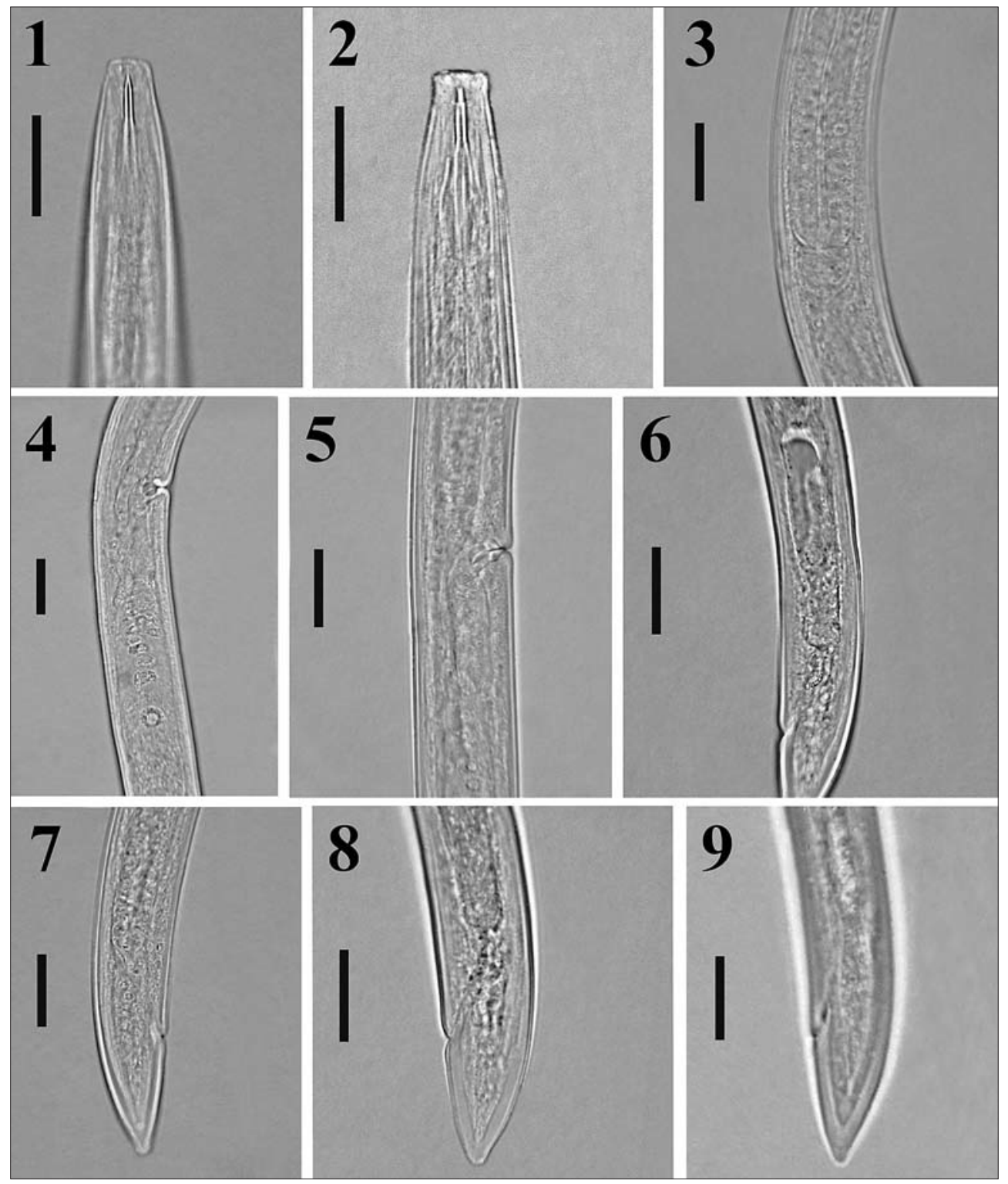

Fig. II - Ecumenicus monohystera - 1, 2. Lip region; 3. Pharyngeal cardia; 4, 5. Vulval region; 6. Prerectum region; 7-9. Posterior region. (Scale bars $=20 \mu \mathrm{m}$ ).

finely striated. Lip region set off by a slight depression, lips distinct. Odontostyle with aperture about one-third length, guiding ring single. Odontophore simple, rod-like. Pharynx enlarges more gradually and basal expansion part of pharynx occupying less than one-half of pharynx length. Dorsal oesophageal gland nucleus located a little bit behind to its orifice. Female genital system monodelphicopistodelphic, Vulva a transverse slit, with slightly sclerotised labia. Vagina oblique. The length of rectum is slightly less than the anal body width. Tail conoid with straight ventral site and digitated rounded tip.

\section{MALE: not found.}

REMARKS: Iranian population of E. monohystera resembled more those described by PeÑA-SANTIAGO \& ABOLAFIA (2007) than some other populations. Compared to Indian population (MushtaQ \& AHMAD, 2007), the ratio c is slightly higher (30.6-40 vs 27.3-30.2), rectum and tail lengths are shorter (15.5-17.5 vs 22-29 $\mu \mathrm{m}$ and 29.0-34.5 vs 34-39 $\mu \mathrm{m}$, respectively). Compared to Bulgarian population (Ilieva et al., 2017), the range of ratio $\mathrm{V}$ is higher (34-39.1 vs 29-34) and rectum length is shorter (15.5-17.5 vs 18-33 $\mu \mathrm{m}$ ). These differences can be attributed to the intraspecific variation due to geographical differences.

E. monohystera is widely distributed in the world and has been reported from Iran by FADAEI-TEHRANI, 2008 (grapevine, Chaharmahal va Bakhtiari province), KASHI NAHANGI \& KAREGAR BIDEH, 2010 (sugar beet, Hamadan) and Hadi-Alijanvand \& FADAeI-TeHRAni, 2013 (wheat, barley and clover, Chaharmahal va Bakhtiari province). In present study, this species was recovered from the rhizosphere of faba bean fields in the vicinity of Shushtar (GPS coordinates: $32^{\circ} 02^{\prime} 44^{\prime \prime} \mathrm{N}, 48^{\circ} 51^{\prime} 24^{\prime \prime} \mathrm{E}$ ) city, Khuzestan province, south-western Iran. This is new record of E. monohystera for nematodes fauna in Khuzestan province. 
Table 1 - Morphometrics of Ecumenicus monohystera collected from south-western Iran and their comparison with some other populations. All measurements are in $\mu \mathrm{m}$ and in the form: mean \pm s.d. (range).

\begin{tabular}{|c|c|c|c|c|}
\hline Character & Present study & $\begin{array}{l}\text { Mushtaq\& Ahmad } \\
(2007)\end{array}$ & $\begin{array}{c}\text { Peña-Santiago \& Abolafia } \\
(2007)\end{array}$ & Ilieva et al. (2017) \\
\hline $\mathrm{n}$ & 14 & 9 & 15 & 11 \\
\hline $\mathrm{L}$ & $\begin{array}{c}1136.9 \pm 98.7 \\
(949-1224)\end{array}$ & $\begin{array}{l}1050 \pm 50.0 \\
(980-1120)\end{array}$ & $\begin{array}{r}1003 \pm 60.0 \\
(910-1140)\end{array}$ & $\begin{array}{r}1120 \pm 70.0 \\
(990-1180)\end{array}$ \\
\hline a & $\begin{array}{c}37.2 \pm 3.4 \\
(31.6-42.2)\end{array}$ & $\begin{array}{l}33.4 \pm 1.4 \\
(31.6-35.0)\end{array}$ & $\begin{array}{c}36.1 \pm 4.4 \\
(31.8-48.0)\end{array}$ & $\begin{array}{l}37.0 \pm 2.0 \\
(34.0-39.0)\end{array}$ \\
\hline $\mathrm{b}$ & $4.8 \pm 0.1(4.6-5.0)$ & $4.6 \pm 0.1(4.3-4.8)$ & $4.7 \pm 0.2(4.3-5.0)$ & $4.6 \pm 0.5(3.9-5.1)$ \\
\hline c & $\begin{array}{c}36.1 \pm 3.0 \\
(30.6-40.0)\end{array}$ & $\begin{array}{l}29.1 \pm 0.8 \\
(27.3-30.2)\end{array}$ & $\begin{array}{l}32.5 \pm 2.6 \\
(29.4-39.8)\end{array}$ & $\begin{array}{c}32.0 \pm 2.0 \\
(31.0-36.0)\end{array}$ \\
\hline $\mathrm{c}^{\prime}$ & $1.5 \pm 0.1(1.4-1.7)$ & $1.6 \pm 0.1(1.5-1.8)$ & $1.6 \pm 0.1(1.3-1.8)$ & $1.6 \pm 0.1(1.5-1.7)$ \\
\hline $\mathrm{V}$ & $\begin{array}{c}36.1 \pm 2.0 \\
(34.0-39.1)\end{array}$ & $\begin{array}{c}35.3 \pm 0.5 \\
(35.0-36.0)\end{array}$ & $\begin{array}{c}35.4 \pm 2.2 \\
(32.0-39.0)\end{array}$ & $\begin{array}{l}32.0 \pm 2 \\
(29-34)\end{array}$ \\
\hline Lip region width & $\begin{array}{c}10.9 \pm 0.5 \\
(10.0-11.5)\end{array}$ & $\begin{array}{c}10.7 \pm 0.4 \\
(10.0-11.0)\end{array}$ & $\begin{array}{c}10.3 \pm 0.5 \\
(10.0-11.0)\end{array}$ & $\begin{array}{c}9.9 \pm 0.2 \\
(9.5-10.0)\end{array}$ \\
\hline Odontostyle length & $\begin{array}{c}10.9 \pm 0.0 \\
(10.5-11.0)\end{array}$ & $\begin{array}{c}12 \pm 0.5 \\
(11.0-13.0)\end{array}$ & $\begin{array}{r}10.1 \pm 0.5 \\
(9.0-11.0) \\
\end{array}$ & $\begin{array}{l}10.0 \pm 0.5 \\
(10.0-11.0)\end{array}$ \\
\hline Neck length & $\begin{array}{c}236.5 \pm 19.9 \\
(198-251)\end{array}$ & $\begin{array}{l}228 \pm 11.8 \\
(210-246)\end{array}$ & $\begin{array}{c}220.0 \pm 12.0 \\
(200-240)\end{array}$ & $\begin{array}{l}245 \pm 17.0 \\
(225-261)\end{array}$ \\
\hline Body width at neck base & $\begin{array}{l}28.7 \pm 1.7 \\
(27.0-32.0)\end{array}$ & $\begin{array}{c}30 \pm 1.0 \\
(28.0-32.0)\end{array}$ & - & $\begin{array}{c}30.0 \pm 2.0 \\
(28.0-32.0)\end{array}$ \\
\hline $\begin{array}{l}\text { Pharyngeal expansion } \\
\text { length }\end{array}$ & $\begin{array}{l}87.5 \pm 10.2 \\
(71.0-95.0)\end{array}$ & $\begin{array}{c}84.1 \pm 3.7 \\
(75.0-87.0)\end{array}$ & $\begin{array}{c}82.2 \pm 7.0 \\
(70.0-90.0)\end{array}$ & - \\
\hline Body width at mid body & $\begin{array}{l}30.5 \pm 1.7 \\
(29.0-34.0)\end{array}$ & $\begin{array}{l}31.5 \pm 1.2 \\
(29.0-33.0)\end{array}$ & $\begin{array}{c}28.9 \pm 3.3 \\
(22.0-33.0)\end{array}$ & $\begin{array}{c}31.0 \pm 1.0 \\
(29.0-32.0)\end{array}$ \\
\hline Anal body width & $\begin{array}{c}19.9 \pm 0.8 \\
(19.0-21.0)\end{array}$ & $\begin{array}{l}20.8 \pm 0.7 \\
(20.0-22.0)\end{array}$ & $\begin{array}{c}20.3 \pm 1.3 \\
(18.0-22.0)\end{array}$ & $\begin{array}{c}22.0 \pm 2.0 \\
(20.0-24.0)\end{array}$ \\
\hline Prerectum length & $\begin{array}{c}46.9 \pm 10.8 \\
(24.3-58.0)\end{array}$ & $\begin{array}{c}40.8 \pm 6.7 \\
(35.0-50.0)\end{array}$ & $\begin{array}{l}35.8 \pm 6.0 \\
(21.0-45.0)\end{array}$ & $\begin{array}{l}41.0 \pm 9.0 \\
(24.0-47.0)\end{array}$ \\
\hline Rectum length & $\begin{array}{c}16.5 \pm 0.9 \\
(15.5-17.5)\end{array}$ & $\begin{array}{l}23.1 \pm 1.5 \\
(22.0-29.0)\end{array}$ & - & $\begin{array}{c}24.0 \pm 6.0 \\
(18.0-33.0)\end{array}$ \\
\hline Tail length & $\begin{array}{c}31.5 \pm 2.0 \\
(29.0-34.5)\end{array}$ & $\begin{array}{l}36.1 \pm 1.4 \\
(34.0-39.0)\end{array}$ & $\begin{array}{l}31.9 \pm 2.1 \\
(27.0-35.0)\end{array}$ & $\begin{array}{l}35.0 \pm 2.4 \\
(32.0-38.0)\end{array}$ \\
\hline
\end{tabular}

\section{Molecular Phylogenetic Status}

The alignment of the D2D3 expansion fragments of $28 \mathrm{~S}$ rRNA gene sequences of 32 taxa (including two out group taxa), yielded a data set with 1194 characters. The phylogenetic relationships between the Iranian population of $E$. monohystera and representatives of Dorylaimida, as inferred from the BI analysis, are presented in Figure III. Phylogenetic relationships among dorylaimid nematodes in this present are mostly congruent with those published by Holterman et al. (2008) and PeÑa -SANTIAGo \& AlvarezOrTEgA (2014). The BI analysis showed that Qudsianematidae are a polyphyletic taxon and some of its genera are closer to members of other families. This result is congruent with previous study focusing on the dorylaimid nematodes (PeÑA-Santiago and Alvarez-Ortega, 2014). Three Ecumenicus sequences were grouped in a clade with high support $(\mathrm{BI}=100)$. This is the first molecular study of E. monohystera in Iran. There were only two records in GenBank for sequences of D2-D3 expansion segments of 28S rRNA gene for the genus Ecumenicus.

In a study by HOLTERMAN et al. (2006) based on small subunit ribosomal DNA (SSU rDNA) gene, the phylogenetic relationships within the order Dorylaimida were fully unclear. Because of low diversity of the SSU rDNA within the order Dorylaimida, Holterman et al. (2008) used the large subunit ribosomal DNA (LSU rDNA) gene for this purpose. The LSU trees show a better resolution within the Dorylaimida, although a large basal polytomy still remained. The relatively high degree of variability of the LSU rDNA genes among nematodes reduces the chances of unwanted cross reactivity considerably (HoLTERMAN et al., 2008).

PeÑa-SAntiago and AlvareZ-Ortega (2014) studied the evolutionary relationships of rounded-tailed dorylaimid genera traditionally classified under the family Qudsianematidae. Evidences were provided that support a closer relationship of these genera with members of Dorylaimidae rather than with other representatives of Qudsianematidae. They believe that the rounded-tailed forms may evolutionary derive from long-tailed forms and transferred eight genera from Qudsianematidae to Dorylaimidae including Labronema Thorne, 1939, Crassolabium Yeates, 1967 (syn. Thonus Thorne, 1974) and Labronemella Andrássy, 1985. Postembryonic development and molecular data of most of these genera has not been studied yet.

Currently, a limited number of the genera among dorylaimid families have been sequenced. As a result, in order to clarify the relationships among genera of these families, a more comprehensive phylogenetic study is 


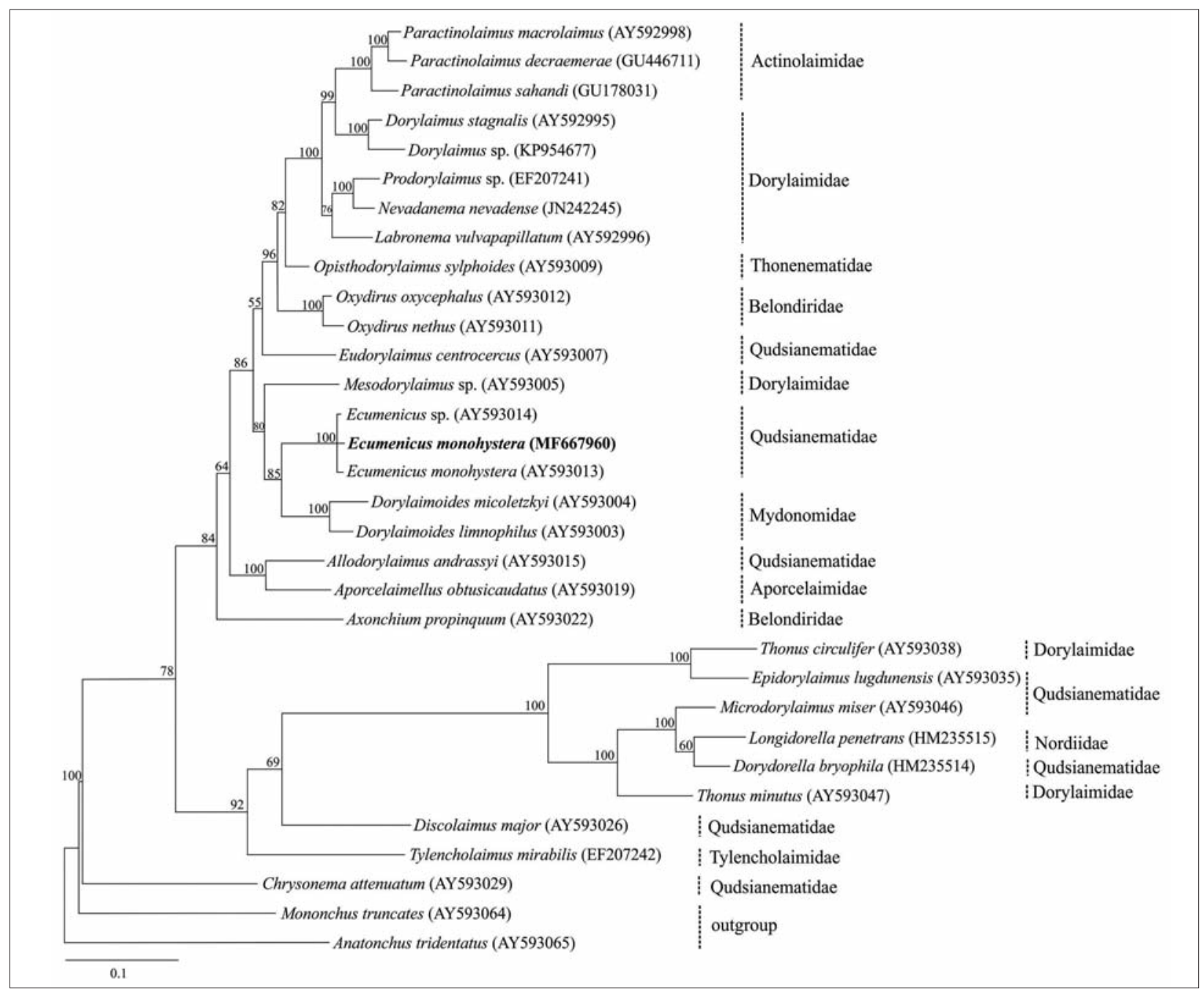

Fig. III - Bayesian 50\% majority rule consensus tree inferred from analysis of the D2-D3 domains of the 28S rRNA gene under the GTR + $\mathrm{G}+\mathrm{I}$ model. Bayesian posterior probability values more than $50 \%$ are given for appropriate clades. New sequence is indicated in bold.

needed, in particular on all available species of these genera from different geographical origins.

\section{ACKNOWLEDGMENTS}

The author gratefully thanks Prof. Dr. Joaquín Abolafia (Department of Animal Biology, Vegetal Biology and Ecology, Universidad de Jaén, Spain) for providing some useful articles, Dr. Majid Pedram (Tarbiat Modares University) for his help and valuable comments and Shahid Chamran University of Ahvaz for financial support.

\section{REFERENCES}

ANDRÁSSY I., 1991 - The superfamily Dorylaimoidea (Nematoda) - a review. Family Qudsianematidae, II. Opusc. Zool. Budapest, 24: 3-55.

DE GRISSE A.T., 1969 - Redescription and modification of some techniques used in the study of nematodes phytoparasitaires. - Meded. Rijks. Landb. Wetensch. Gent, 34: 351-369.

FADAEI-TEHRANI A.A., 2008 - Introduction some species
Dorylaimid nematodes from vineyards of Chaharmahal va Bakhtiari province. Proceedings of $18^{\text {th }}$ Iranian Plant Protection Congress. Vol. II. Plant diseases, Hamedan, Iran, p: 565.

Hadi-AlijanVand E., FAdAeI-Tehrani A.A., 2013 - Species of the family Qudsianematidae (Nematoda: Dorylaimida) from Chaharmahal va Bakhtiari province, Iran. - Iranian Journal of Plant Pathology, 49 (2): 241-255. (In Persian).

Holterman M., Man Der Wurff A., Van Den Elsen S., Van Megen H., Bongers T., Holovachov O., BaKker J., HELdER J., 2006 - Phylum-wide analysis of SSU rDNA reveals deep phylogenetic relationships among nematodes and accelerated evolution toward crown clades. - Mol. Biol. Evol., 23: 1792-1800.

Holterman M., RybarczyK K., Van Den Elsen S., Van Megen H., Mooyman P., PeÑa -Santiago R., Bongers T., BAKKer J., Helder J., 2008 - A ribosomal DNAbased framework for the detection and quantification of stress-sensitive nematode families in terrestrial habitats. Mol. Ecol. Resources, 8: 23-34.

Huson D., Scornavacca C., 2012 - Dendroscope 3: An interactive tool for rooted phylogenetic trees and networks. - Syst. Biol., 61: 1065-1067.

Ilieva Z.I., ILIEV I.L., GeorgievA V.G., 2017 - New data on 
nematodes of the families Aporcelaimidae, Paraxonchidae, Qudsianematidae and Dorylaimidae based on examinations of a raspberry plantation in Bulgaria. Acta Zool. Bulg., 69 (2): 171-192.

JENKINS W.R. 1964 - A rapid centrifugal flotation technique for separating nematodes from soil. - Pl. Dis. Reptr., 48: 692.

Kashi NAHANGi L., KaREgar BiDEH A., 2010 - First report of some species of order Dorylaimida from Iran. Proceedings of $19^{\text {th }}$ Iranian Plant Protection Congress. Vol. II. Plant diseases, Tehran, Iran, p: 599.

LARGET B., Simon D.L., 1999 - Markov chain Monte Carlo algorithms for the Bayesian analysis of phylogenetic trees. - Mol. Biol. Evol., 16: 750-759.

Mushtaq P., Ahmad W., 2007 - Some new and known species of the family Qudsianematidae (Nematoda: Dorylaimida) from Jammu and Kashmir, India. - J. Nem. Morph. Syst., 9 (2): 153-178.

NunN G.B., 1992 - Nematode molecular evolution. PhD Thesis, University of Nottingham, Nottingham, U.K., 192 pp.

NYLANDER J.A.A., 2004 - MrModeltest v2. Evolutionary
Biology Centre, Uppsala University. Available from: http://www.ebc.uu.se/ systzoo/staff/nylander.html (accessed 14 April 2014).

Pedram M., Pourjam E., Ye w., Atighi M.R., Robbins R.T., RYss A., 2011 - Description of Bursaphelenchus mazandaranense sp. n. (Nematoda: Parasitaphelenchidae) from Iran. - Russ. J. Nematol., 19 (2): 121129.

Peña-Santiago R., Abolafia J. 2007 - Notes on the genus Ecumenicus Thorne, 1974 (Dorylaimida: Qudsianematidae). - J. Nem. Morph. Syst., 10 (1): 97-100.

Peña-Santiago R., Alvarez-Ortega S., 2014 - An integrative approach to assess the phylogeny and the systematics of rounded-tailed genera of the subfamily Qudsianematinae (Nematoda, Dorylaimida). - Zool. Scr., 43: 418-428.

Ronquist F., Huelsenbeck J.P., 2003 - MrBayes 3: Bayesian phylogenetic inference under mixed models. Bioinformatics, 19: 1572-1574.

SIDDIQI M.R., 2000 - Tylenchida: parasites of plants and insects. CABI Publishing, Wallingford, UK, 833 pp. 